\title{
Improving Learning Outcomes in Thematic Learning Through Audio Visual Media for Third Grade Students of SDN Kauman 01
}

\author{
Pangrango Niken Prastiwi \\ SD Negeri Kauman 01 \\ prastiwi.okay@gmail.com
}

\begin{tabular}{lll}
\hline Article History & approved 08/11/2020 & published 15/11/2020 \\
accepted 01/11/2020
\end{tabular}

\begin{abstract}
This reseach entitled "Improving learning outcomes in thematic learning through audio-visual media for third grade students of SDN Kauman 01". The purpose of this study was to improve student learning outcomes through audio-visual media. This research uses Classroom Action Research (PTK). The subjects of this study were third grade students of SD Negeri Kauman 01 Batang in the first semester of the 2020/2021 school year. The success of this study was observed based on the percentage of completeness of student learning outcomes obtained from the evaluation test scores at the end of each cycle. Students are declared complete learning when they reach a value of 70 and one class is declared complete learning if they have reached a percentage of $85 \%$ of students who have scored 70 or more. After carrying out classroom action research, it was concluded that audio-visual media can improve student learning outcomes in class III thematic learning.
\end{abstract}

Keywords: thematic, audio visual, elementary school

\begin{abstract}
Abstrak
Penelitian ini berjudul "Peningkatan hasil belajar pada pembelajaran tematik melalui media audio visual siswa kelas III SDN Kauman 01". Tujuan penelitian ini adalah untuk meningkatkan hasil belajar siswa melalui media audio visual. Penelitian ini menggunakan Penelitian Tindakan Kelas (PTK). Subjek Penelitian ini adalah siswa kelas III SD Negeri Kauman 01 Batang semester I tahun pelajaran 2020/2021. Keberhasilan penelitian ini diamati berdasarkan prosentase ketuntasan hasil belajar siswa yang diperoleh dari nilai tes evaluasi setiap akhir siklus. Siswa dinyatakan tuntas belajar apabila mencapai nilai $\geq 70$ dan satu kelas dinyatakan tuntas belajar apabila telah mencapai prosentase $85 \%$ siswa yang mendapat nilai 70 atau lebih. Setelah melaksanakan penelitian tindakan kelas, disimpulkan bahwa media audio visual dapat meningkatkan hasil belajar siswa pada pembelajaran tematik kelas III.
\end{abstract}

Kata kunci: tematik, audio visual, sekolah dasar

Social, Humanities, and Education Studies (SHEs): Conference Series https://jurnal.uns.ac.id/shes 


\section{PENDAHULUAN}

Sistem pendidikan nasional menggariskan bahwa pembangunan di bidang pendidikan adalah upaya untuk mencerdaskan kehidupan bangsa dan meningkatkan kualitas manusia Indonesia dalam mewujudkan mengembangkan diri, adil dan makmur serta memungkinkan para warganya mengembangkan diri, baik berkenaan dengan aspek jasmani dan rohani berdasarkan Pancasila dan UUD 1945.

Masa Pandemi Corona Virus 19 (covid 19) ini membuat proses pembelajaran yang biasanya dilaksanakan dengan tatap muka di depan kelas, tidak dapat dilaksanakan lagi, hal ini karena adanya kekhawatiran makin menyebarnya covid19. Perlunya inovasi media pembelajaran untuk menunjang kualitas pembelajaran yang baik demi keberlangsungan pendidikan bangsa indonesia.

Rendahnya mutu akademik dan proses pembelajaran yang secara umum dialami Bangsa Indonesia, juga terjadi di sekolah tempat peneliti bertugas yaitu SDN Kauman 01 Kecamatan Batang Kabupaten Batang. Hal ini dapat dilihat dari rendahnya hasil belajar yang diperoleh siswa. Hasil evaluasi pada pembelajaran tematik dari 31 siswa yang mendapat nilai 70 keatas hanya 8 anak. Ini berarti yang dapat menguasai materi hanya $26 \%$. Anak yang lainnya sebanyak $74 \%$ belum mencapai ketuntasan.

Sebagai upaya untuk memperbaiki hasil evaluasi pada pembelajaran tematik tersebut, peneliti melakukan penelitian tindakan kelas (PTK). Langkah selanjutnya sebagai upaya untuk mencari permasalahan yang dihadapi, peneliti melakukan refleksi.

Penelitian Tindakan Kelas (PTK) merupakan kegiatan penelitian yang dilakukan terhadap sejumlah subjek yang menjadi sasaran yaitu peserta didik, bertujuan memperbaiki situasi pembelajaran di kelas agar terjadi peningkatkan kualitas pembelajaran (Suharsimi Arikunto : 2010).

Pengertian belajar menurut KBBI (Kamus Besar Bahasa Indonesia) adalah berusaha memperoleh kepandaian atau ilmu, berlatih, berubah tingkah laku atau tanggapan yang disebabkan oleh pengalaman. Menurut kamus besar Bahasa Indonesiaa peningkatan merupakan proses, cara, perbuatan meningkat (usaha, kegiatan, dsb) Pengertian hasil belajar Hasil belajar merupakan kemampuan-kemampuan dimiliki siswa setelah menerima pengalaman belajarnya. Kemampuan-kemampuan tersebut mencakup aspek kognitif, afektif dan psikomotorik. Hasil belajar dapat dilihat melalui kegiatan evaluasi yang bertujuan untuk mendapatkan data pembuktian yang akan menunjukkan tingkat kemampuan siswa dalam mencapai tujuan pembelajaran. Hasil belajar ialah perubahan yang mengakibatkan manusia berubah dalam sikap dan tingkah lakunya.(Purwanto : 2010)

Menurut Majid (2014), pembelajaran tematik adalah pembelajaran yang menggabungkan suatu konsep dalam beberapa bidang studi yang berbeda dengan harapan siswa akan belajar lebih baik dan bermakna.

\section{Kelebihan dan Kelemahan Pembelajaran Tematik}

Setiap bentuk model pembelajaran memiliki kelebihan dan kekurangan masingmasing. Menurut Majid (2014), kelebihan dan kekurangan pembelajaran tematik di antaranya: pengalaman belajar dan kegiatan belajar akan sesuai dengan tingkat perkembangan siswa; kegiatan belajar dapat disesuaikan dengan minat dan kebutuhan siswa; kegiatan belajar lebih bermakna.; mengembangkan keterampilan berpikir dan keterampilan sosial siswa; menyajikan kegiatan bersifat pragmatis yang dekat dengan keseharian siswa; meningkatkan kerjasama antar guru dalam merancang kegiatan pembelajaran. Sebaliknya, kelemahan atau kekurangan pembelajaran tematik, antara lain: Pembelajaran tematik, mengharapkan guru memiliki wawasan luas, kreativitas tinggi, percaya diri, dan kemampuan handal menggali informasi dan pengetahuan terkait materi. Tanpa kemampuan guru yang mumpuni, pembelajaran tematik akan sulit diterapkan. Pembelajaran tematik mengharapkan siswa memiliki kemampuan 
akademik dan kreativitas, sehingga keterampilan-keterampilan siswa dapat terbentuk ketika pembelajaran ini dilaksanakan. Pembelajaran tematik memerlukan sarana dan sumber pembelajaran yang bervariasi. Pembelajaran tematik memerlukan dasar kurikulum yang luwes atau fleksibel. Pembelajaran tematik membutuhkan cara penilaian yang menyeluruh atau komprehensif

Kata media berasal dari bahasa latin medius yang secara harfiah berarti tengah, perantara atau pengantar. Sedangkan pengertian media menurut Usman dan M. Basyiruddin Asnawir adalah sesuatu yang bersifat menyalurkan pesan dan dapat merangsang pikiran, perasaan, dan kemauan audien (siswa) sehingga dapat mendorong terjadinya proses belajar pada dirinya. Menurut Sri Anitah (2012:51), "media audio visual adalah media yang menunjukkan unsur auditif (pendengaran) maupun visual (penglihatan), jadi dapat dipandang maupun

didengar suaranya."

Berdasarkan uraian diatas, maka rumusan masalah dalam penelitian ini adalah apakah melalui media audio visual dapat meningkatkan hasil belajar pada pembelajaran tematik siswa kelas III SDN Kauman 01? Penelitian ini bertujuan untuk meningkatkan hasil belajar pada pembelajaran tematik menggunakan media audio visual siswa kelas III semester 1 SDN Kauman 01 Kecamatan Batang Kabupaten Batang tahun pelajaran 2020/2021.

\section{METODE}

Penelitian yang digunakan dalam penelitian ini adalah penelitian tindakan kelas (PTK). Penelitian ini dilakukan mulai tanggal 22 Oktober 2020 sampai dengan 14 November 2020. Subjek penelitian tindakan kelas (PTK) ini adalah siswa kelas III SD Negeri Kauman 01 Kecamatan Batang Kabupaten Batang Jawa Tengah dengan jumlah siswa 32 terdiri dari 11 laki - laki dan 20 perempuan. Pengumpulan data pada penelitian ini adalah melalui rangkaian tes baik lisan maupun tertulis. Penilaian hasil belajar siswa menggunakan tes evaluasi, lembar tes evaluasi siswa untuk nilai terendah dan nilai tertinggi terlampir. Teknik pengamatan peneliti melaksanakan pengajaran secara daring menggunakan platform google meet kemudian pengamat mengamati jalannya pembelajaran dan mengisikan data pada lembar observasi. Dalam penelitian tindakan kelas ini peneliti menggunakan teknis analisis data deskriptif untuk mengetahui hasil belajar siswa. Analisis data deskriptif mengacu pada transformasi dari data - data mentah kedalam suatu bentuk yang mudah dimengerti dan diterjemahkan. Pendeskripsian respons atau hasil observasi merupakan ciri khas dari bentuk pertama analisis. Perhitungan rata - rata, distribusi frekuensi dan distribusi presentase adalah bentuk yang paling umum dari peringkasan data.

\section{Siklus I}

\section{HASIL DAN PEMBAHASAN}

Siklus I terdiri dari empat tahap yaitu tahap perencanaan, tahap pelaksanaan, tahap pengamatan dan tahap refleksi.

a. Tahap perencanaan

Pada tahap ini mempersiapkan beberapa hal, yaitu menetapkan materi yang akan diajarkan, menyusun Rencana Pelaksanaan Pembelajaran (RPP I) dengan mengacu pada siklus. Selain itu, peneliti juga menyusun alat evaluasi kepada siswa yang akan memperoleh tindakan,berupa : Lembar Kerja Peserta Didik (LKPD), soal tes (post test) serta instrumen pengamatan aktivitas guru dan aktivitas siswa.

b. Tahap Pelaksanaan (Acting)

Tahap pelaksanaan (Acting) RPP I, dilaksanakan pada tanggal 22 Oktober 
2020. Kegiatan pembelajaran dibagi ke dalam tiga tahap, yaitu pendahuluan (kegiatan awal), Kegiatan inti dan kegiatan akhir (penutup).

c. Tahap Pengamatan (Observation) Observasi dilakukan selama proses kegiatan pembelajaran siklus I berlangsung. Observasi dilakukan terhadap, aktivitas guru, aktivitas siswa selama pembelajaran berlangsung, hasil belajar siswa dengan menggunakan media audio visual.

d. Tahap Refleksi pada Siklus I

Berdasarkan tindakan pada siklus I meliputi perencanaan dan pelaksanaan tindakan serta hasil observasi dapat dilakukan hasil refleksi. Peneliti dan kolaborator mendiskusikan hasil pelaksanaan tindakan. Upaya untuk meningkatkan hasil belajar siswa melalui media audio visual masih belum menunjukkan hasil yang maksimal. Pada pembelajaran siklus I perolehan nilai tes evaluasi yaitu rata-rata kelas mencapai 72,58 dan prosentase ketuntasan mencapai $55 \%$. Dengan demikian, perlu adanya perbaikan siklus II karena perolehan nilai hasil belajar belum maksimal mencapai tingkat ketuntasan.

\section{Siklus II}

Siklus II terdiri dari empat tahap yaitu tahap perencanaan, tahap pelaksanaan, tahap pengamatan dan tahap refleksi.

a. Tahap perencanaan

Pada tahap ini mempersiapkan beberapa hal, yaitu menetapkan materi yang akan diajarkan, menyusun Rencana Pelaksanaan Pembelajaran (RPP 2) dengan mengacu pada siklus. Selain itu, peneliti juga menyusun alat evaluasi kepada siswa yang akan memperoleh tindakan, berupa : Lembar Kerja Peserta Didik (LKPD), soal tes (post test) serta instrumen pengamatan aktivitas guru dan aktivitas siswa.

b. Tahap Pelaksanaan (Acting)

Tahap pelaksanaan (Acting) RPP 2, dilaksanakan pada tanggal 2 November 2020. Kegiatan pembelajaran dibagi ke dalam tiga tahap, yaitu pendahuluan (kegiatan awal), Kegiatan inti dan kegiatan akhir (penutup). Tahap Pengamatan (Observation)

Observasi dilakukan selama proses kegiatan pembelajaran siklus II berlangsung. Observasi dilakukan terhadap, aktivitas guru, aktivitas siswa selama pembelajaran berlangsung, hasil belajar siswa dengan menggunakan media audio visual.

d. Tahap Refleksi pada Siklus II

Berdasarkan tindakan pada siklus II meliputi perencanaan dan pelaksanaan tindakan serta hasil observasi dapat dilakukan hasil refleksi. Peneliti dan kolaborator mendiskusikan hasil pelaksanaan tindakan. Upaya untuk meningkatkan hasil belajar siswa melalui media audio visual masih belum menunjukkan hasil yang maksimal. Perolehan hasil perbaikan pembelajaran pada siklus II menunjukkan peningkatan, yaitu rata-rata kelas mencapai 78,71 dan prosentase ketuntasan mencapai $77 \%$. Untuk itu masih perlu diadakan perbaikan pada siklus III karena perolehan hasil belajar belum mencapai tingkat ketuntasan.

\section{Siklus III}

Siklus III terdiri dari empat tahap yaitu tahap perencanaan, tahap pelaksanaan, tahap pengamatan dan tahap refleksi.

a. Tahap perencanaan

Pada tahap ini mempersiapkan beberapa hal, yaitu menetapkan materi yang akan diajarkan, menyusun Rencana Pelaksanaan Pembelajaran (RPP 3) 
dengan mengacu pada siklus. Selain itu, peneliti juga menyusun alat evaluasi kepada siswa yang akan memperoleh tindakan, berupa : Lembar Kerja Peserta Didik (LKPD), soal tes (post test) serta instrumen pengamatan aktivitas guru dan aktivitas siswa.

b. Tahap Pelaksanaan (Acting)

Tahap pelaksanaan (Acting) RPP 3, dilaksanakan pada tanggal 13 November 2020. Kegiatan pembelajaran dibagi ke dalam tiga tahap, yaitu pendahuluan (kegiatan awal), Kegiatan inti dan kegiatan akhir (penutup).

c. Tahap Pengamatan (Observation)

Observasi dilakukan selama proses kegiatan pembelajaran siklus III berlangsung. Observasi dilakukan terhadap, aktivitas guru, aktivitas siswa selama pembelajaran berlangsung, hasil belajar siswa dengan menggunakan

d. Tahap Refleksi pada Siklus III

Berdasarkan tindakan pada siklus III meliputi perencanaan dan pelaksanaan tindakan serta hasil observasi dapat dilakukan hasil refleksi. Peneliti dan kolaborator mendiskusikan hasil pelaksanaan tindakan. Upaya untuk meningkatkan hasil belajar siswa melalui media audio visual sudah menunjukkan hasil yang lebih baik. Perolehan hasil perbaikan pembelajaran pada siklus III menunjukkan peningkatan yang cukup signifikan, yaitu rata-rata kelas mencapai 88,06 dan prosentase ketuntasan mencapai $97 \%$. Sehingga target ketuntasan hasil belajar siswa di kelas III SD Negeri Kauman 01 tercapai. Maka penelitian ini dihentikan.

Tabel 1. Data Nilai Hasil Belajar Siswa Kelas III Pembelajaran Tematik

\begin{tabular}{llcccc}
\hline \hline \multirow{2}{*}{ No } & Uraian & \multicolumn{2}{c}{ Siswa yang tuntas } & \multicolumn{2}{c}{ Siswa yang belum tuntas } \\
& & Frekuensi & Prosentase & Frekuensi & Prosentase \\
\hline 1. & Siklus I & 17 & $55 \%$ & 14 & $45 \%$ \\
2. & Siklus II & 24 & $77 \%$ & 8 & $23 \%$ \\
3. & Siklus III & 30 & $97 \%$ & 1 & $3 \%$ \\
\hline
\end{tabular}




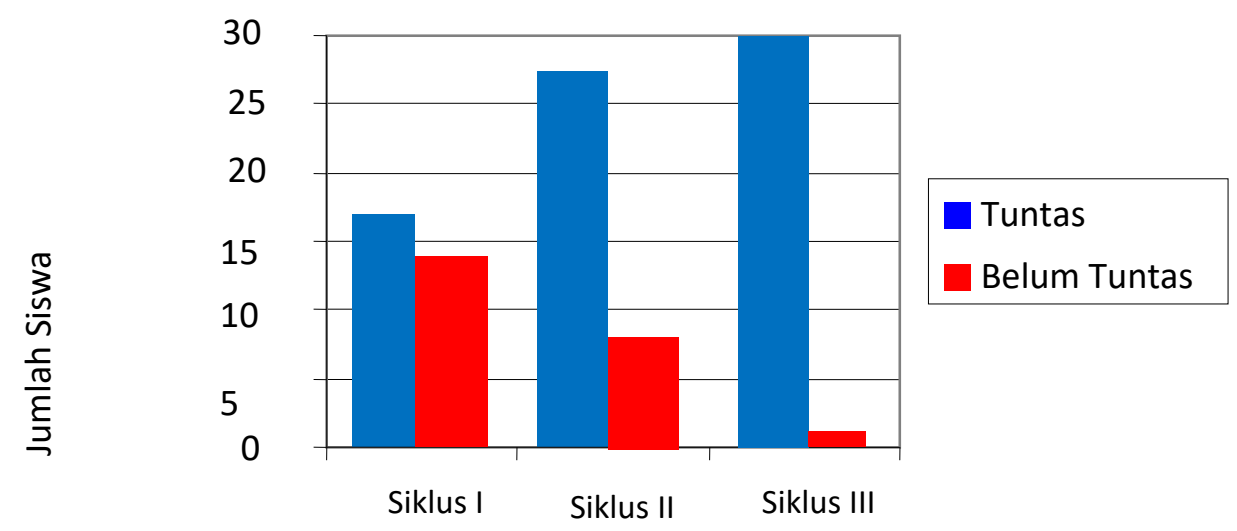

\section{Gambar 1. Grafik Ketuntasan Hasil Belajar Pembelajaran Tematik}

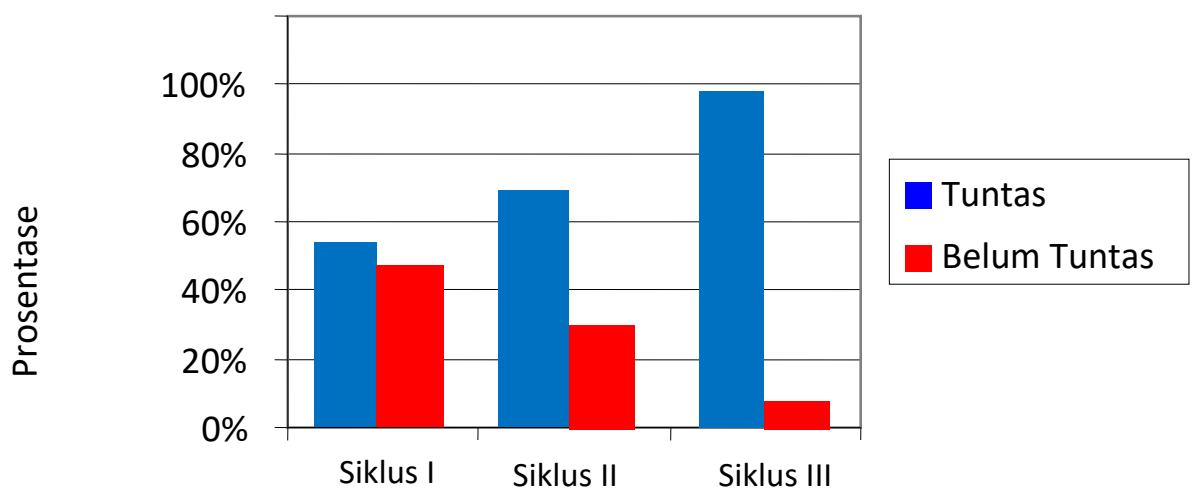

\section{Gambar 2. Grafik Prosentase Hasil Belajar Pembelajaran Tematik}

Dari tabel dan grafik diatas terlihat bahwa prosentase ketuntasan siklus I meningkat sebanyak $22 \%$ yaitu dari $55 \%$ pada siklus I menjadi $77 \%$ pada siklus II. Sedangkan peningkatan dari siklus II ke siklus III sebanyak $20 \%$, terlihat dari prosentase ketuntasan siklus II 77\% dan siklus III 97\%. Selain prosentase ketuntasan yang meningkat pada tiap siklus, frekuensi jumlah siswa yang tuntas juga meningkat. Sebanyak 17 siswa pada siklus I, 24 siswa pada siklus II, dan 30 siswa pada siklus III telah mencapai ketuntasan.

Pada setiap siklus menggunakan media audio visual sebagai media pembelajaran secara daring. Penggunaan media audio visual dapat merangsang pikiran, dan perasaan siswa melalui penglihatan dan pendengaran. Berdasarkan hasil pembahasan diatas dapat disimpulkan bahwa penggunaan media audio visual dapat meningkatkan hasil belajar siswa kelas III pada pembelajaran tematik. Hal ini sejalan dengan penelitian yang dilakukan oleh Rizki Ananda (2017) yaitu Penggunaan Media 
Audio Visual untuk Meningkatkan Hasil Belajar Pendidikan Kewarganegaraan Siswa Kelas IV SD Negeri 016 Bangkinang Kota.

\section{SIMPULAN}

Dari paparan hasil penelitian tindakan kelas (PTK), setelah dilakukan perbaikan pembelajaran tematik pada SD Negeri Kauman 01 kelas III semester 1 dapat disimpulkan bahwa adanya perbaikan pembelajaran dengan menggunakan media audio visual dapat meningkatkan hasil belajar siswa. Keberhasilan ini dapat dilihat dari semakin meningkatnya nilai rata-rata kelas tes evaluasi pada siklus I siswa hanya memperoleh nilai rata-rata 72,58 dengan prosentase $55 \%$ siswa yang tuntas, pada siklus II ternyata memperoleh nilai rata-rata 78,71 dengan prosentase $77 \%$ berarti mengalami kenaikan 22\%. Pada siklus III mengalami peningkatan 20\% dengan prosentase ketuntasan $97 \%$ dengan nilai rata-rata 88,06. Meningkatnya hasil belajar siswa tidak lepas dari adanya perbaikan pembelajaran yang dilakukan oleh guru di yaitu penggunaan media audio visual untuk lebih memudahkan siswa menerima materi yang diajarkan. Berdasarkan kesimpulan diatas maka peneliti menyarankan agar guru lebih kreatif dalam penggunaan media pembelajaran. Penerapan guru dalam meningkatkan hasil belajar melalui PTK (penelitian tindakan kelas) hendaknya semakin ditingkatkan mutunya dan dapat dikembangkan di sekolah masing-masing

\section{DAFTAR PUSTAKA}

Ananda, Rizki. (2017). Penggunaan Media Audio Visual untuk Meningkatkan Hasil Belajar Pendidikan Kewarganegaraan Siswa Kelas IV SD Negeri 016 Bangkinang Kota. Jurnal Basicedu Volume 1 Nomor 1 Tahun 2017 Halaman 21-30. DOI: https://doi.org/10.31004/basicedu.v1i1.149

Anitah, Sri. (2012). Media Pembelajaran. Surakarta: Yuma Pustaka

Arikunto, Suharsimi (2010). Prosedur Penelitian: Suatu Pendekatan Praktek. Jakarta: Rineka Cipta.

Daryanto. (2013). Media Pembelajaran Peranannya Sangat Penting Dalam Mencapai Tujuan Pembelajaran, Yogyakarta : Gava Media.

Kajian Pustaka. (2020). Pembelajaran tematik. https://www.kajianpustaka.com/2020/06/pembelajaran-tematik.html

KBBI. Pengertian Belajar. https://www.zonareferensi.com/pengertian-belajar/

KBBI. Pengertian peningkatan. https://typoonline.com/kbbi/Meningkatkan Majid, Abdul. (2014). Strategi Pembelajaran. Bandung: Remaja Rosdakarya Dosen pendidikan. Hasil Belajar. https://www.dosenpendidikan.co.id/hasil-belajar/ 